\title{
ANTECEDENTS AND CONSEQUENCES OF SOCIAL ISSUE ADVERTISING BELIEVABILITY
}

\author{
Deborah Griffin \\ Griffith University \\ Aron O'Cass \\ The University of Newcastle \\ Track: Political, Social and Not-for-Profit Marketing \\ Keywords: ad believability, social issue advertising
}

\begin{abstract}
Advertising of social issues has become an important element of social marketing. However, little assessment of social advertising believability has been undertaken. This is further compounded by a lack of attention to the antecedents and consequences of how believable the target audience see the advertised messages. This study focused on examining social advertising by gathering data on two social issues being advertised. The results indicate that social issue involvement influenced social advertising believability, and believability and involvement influenced attitudes toward social issues. In addition, attitude influenced intention to comply with the social issue message.
\end{abstract}

\section{Introduction}

It seems that many of the problems facing society today involve behavioural choices that include activities such as drinking alcohol, smoking cigarettes, taking drugs and the like. For example, smoking and excessive drinking have significant social costs as indicated by findings of 1998 National Drug Strategy that found tobacco and alcohol consumption to be the major cause of drug related deaths in Australia (Higgins Stanbury-Cooper \& Williams 2000). Accordingly, there has been an increasing trend by governments and non-profit organisations to use social marketing to address behaviours that result from such choices particularly when they become problems at a societal level. On this, many have attempted to address social problems through extensive television advertising campaigns. As such, this study examines two social issues (i.e. anti-smoking and anti-drinking) from the perspective of the believability of the advertisements and the antecedents affecting believability - such as an individual's involvement in the issue (pro or positive), their attitude towards the issue, the attention paid to issue related advertising messages, and impact they have on an individual's intention to comply.

\section{Background to Social Issue Advertising}

Over the years researchers have examined advertising from the perspective of source credibility (Gotlieb \& Sarel 1991) attitude towards the ad (Burton \& Lichtenstein 1988; Neece \& Capella 1996) and involvement in advertising (Greenwald \& Leavitt 1984; Laczniak \& Muehling 1993). However, an area that to some extent has been overlooked, is the believability of advertising, and given that advertising plays a significant role in social marketing campaigns, it would seem that ad believability is relevant to the theme of social issues, their advertising and ultimate effectiveness. For instance, social advertising is a 
favoured method of disseminating warning messages (Carroll 1996; Peracchio \& Luna 1998; Pechmann \& Reibling, 2000; Wolburg 2001), as such, it would seem that the degree to which the advertisements are believed, may impact on the target audience's attitudes and intention to comply with the messages.

The concept of ad believability as proposed by Beltramini (1982) suggests it is the extent to which an ad evokes sufficient confidence in its truthfulness making it acceptable to consumers. Believability focuses on the message and its content (not the source and its credibility). The relevance of believability to social issues has been applied to information contained in cigarettes advertising (Beltramini 1988) and alcohol warning labels (Andrews Netemeyer \& Durvasula, 1990; 1991). It has also been examined by O'Cass (2002) in the context of the believability of political advertising which demonstrated that believability of political ads is influenced by involvement of voters in elections, as such, we may also expect that believability of social issue messages and involvement in social issues are related. Using Zaichkowsky's (1985 p.342) definition of involvement as "a person's perceived relevance of the object based on inherent needs, values and interests", in our view, social issue involvement refers to the extent the individual finds the positive or pro behaviour (as the object) involving, rather than the anti-social or negative behaviour (O'Cass 2000). This being the case, involvement in, for example, the anti-smoking or anti-drinking issue suggests a greater focus on the negative consequences of the behaviours (i.e. smoking cigarettes or drinking to excess). Thus, high social issue involvement as such, is when the social issue has high personal relevance (Hajjat 2003).

It is argued that the more personally relevant an issue, the more motivated individuals are to evaluate issue relevant arguments (Petty \& Cacioppo 1979). This suggests an individual involved in a social issue may be more likely to think about the theme or message of the related social advertisement. That is, think about the negative consequences of smoking or drinking to excess portrayed in the ad, leading them to maintain their attitude or strengthen their attitude (in a positive manner). Thus, individuals involved in the anti-drinking social issue, such involvement will positively influence their attitude towards the issue, and against drinking to excess. Conversely, individuals not involved in and who practise the aberrant behaviour, would not be motivated to evaluate arguments contained in the advertisement, hence, there may be no change in their negative attitude. As such,

\section{H1: Involvement in a social issue will influence attitude towards the issue.}

Further, the level of involvement determines (to some extent) how much attention an individual allocates to a message (Greenwald \& Leavitt 1984), in that higher involvement translates into greater attention paid to an ad (Kokkinaki \& Lunt 1999). Hence, an individual who is highly involved in, for example, the anti-smoking social issue, should want to acquire more information about the issue, and pay more attention to advertising of the issue (Lee et al. 1999). Further, as a result of the ongoing relevance of a stimuli (i.e. anti-smoking issue), individuals should be more attentive and willing to process related information (Buchholz \& Smith, 1991; Gill, Grossbart \& Laczniak,1988). This point has also been noted by Hajjat (2003). As such,

\section{H2: Involvement in a social issue will influence the level of attention paid to the social advertisement for the issue.}

Given the arguments that involved individuals pay more attention to related information, it is reasonable to then argue that such attention will also be derived through believing the advertising theme or message. Drawing these points together we argue that those more involved will pay more attention to related information (e.g., anti-smoking), and subsequently, such individuals will believe the communicated messages and subsequently pay more attention to advertising about the issue. As such, 


\section{H3: The believability of a social issue advertisement will influence the attention paid to subsequent advertisement for the issue.}

However, for those individuals who believe that smoking or drinking to excess is not a health risk, exposure to anti-smoking or anti-drinking message may not change that belief. As such, social marketers may be dealing with a group of individuals highly resistant to warnings against engaging in problem behaviours. Laczniak and Muehling (1993) maintain that messages aimed at these receivers would need to be persuasive enough to help in the formation of strong beliefs (i.e. smoking or drinking to excess are health risks), because individuals with higher issue involvement see more relevance and are more likely to believe the communicated messages. As such,

\section{H4: Involvement in a social issue will influence the believability of the social advertisement for the issue.}

Although the aim of social marketing is primarily to change behaviours (Andreasen 1995), attitudes play an important role in predicting behaviour (Fishbein \& Ajzen 1975; Sheppard, Hartwick \& Warshaw 1988). Attitudes may be seen as "global and relatively enduring evaluations of objects, issues or persons" (Petty Unnava \& Strathman 1991, p. 242). Fazio Powell and Williams (1989) maintain attitudes formed through personal experiences will be more likely to predict behaviour, than attitudes formed through an indirect marketing communication. Relating this argument to social marketing and the influence of Public Service Announcements, it would seem that those individuals who smoke or drink to excess may be more likely to form their attitudes based on their experience with the product (e.g. alcohol and cigarettes), rather than an anti-smoking or anti-drinking ad. As such, the social advertisement may have little influence in changing their negative attitudes. However, according to Raymond Tanner and Eppright (1998) believable sources may possibly motivate or reinforce healthy behaviours, which implies that if a message is believed it will influence attitudes in a positive direction. As such,

\section{H5: The believability of a social issue advertisement will influence attitude towards the issue.}

Fishbein and Ajzen (1975) suggest most behaviours can be predicted as a result of the individual's intention to carry out the behaviour in question. From a social marketing perspective, in order to link attitude change with behaviour, Snyder and Kendzierski (1982) suggest an individual must be aware of the relevance of the attitude to the particular situation. For example, a positive attitude towards anti-smoking needs to be linked to an individual's belief that 'every cigarette is doing me damage'. Thus, new attitudes may be translated into new behaviours when people are persuaded that 'believing means doing' (Snyder \& Kendzierski 1982). As such,

\section{H6: Attitude toward a social issue will influence intention to comply with the social} marketing campaign for the issue.

\section{Research Design}

A self-completed questionnaire was administered to a convenience sample of undergraduate students at an Australian university, with approximately half the sample responding to the anti-smoking survey and half to the anti-drinking survey, resulting in 300 useable surveys being completed. Items to measure involvement in the social issue were measured via Zaichkowsky's Personal Involvement Inventory scale (1985). A pool of items was generated to measure respondents' attitudes towards the behaviour of smoking cigarettes and drinking alcohol and attention paid to anti-smoking and anti-drinking advertisements. These items were generated through a deductive process as well as a review of extant literature (Mittal 1990; Mano 1997; Laczniak, Muehling \& Grossbart, 1989). Believability of the social 
advertising was measured using Beltramini's (1982) TV Advertising Believability Scale. Items from each scale were computed to form composite variables following the conventions of Beltramini (1982) and O'Cass (2001). The study used a 7-point scale format, and wording of the items in each instrument was the same, except in respect to each social issue - antismoking and anti-drinking.

As part of the study, respondents were required to watch two advertisements from the National Alcohol and Tobacco Campaigns. Each group only watched the ads that related to their particular issue. The key message associated with the ads was emphasized by the slogan for the campaign - 'How will you feel tomorrow' for the anti-drinking campaign and 'Every cigarette is doing you damage' for the anti-smoking campaign.

All constructs showed acceptable reliability, with Cronbach's Alpha of .76 or greater indicating high reliability. Analysis of the measures showed that for all the measures factor loadings were greater than .60. The ages of the respondents ranged from 17 to 30 (mean age = $21)$ with the majority of respondents under 23 years of age $(72 \%)$. Female respondents accounted for approximately $59 \%$ of the total sample and the distribution of respondents across the sample for each issue was approximately even. Following the preliminary analysis all items within each construct were computed into composite variables to test the hypotheses.

\section{Results of Relationships H1 to H7}

Partial Least Squares (PLS) was used to analyse the data after consideration of the proposed relationships and sample size in the two issues (O'Cass 2001). A systematic examination of a number of fit indices for predictive relevance of the model was necessary (Fornell \& Cha 1994) including, $\mathrm{R}^{2}$, average variance accounted (AVA), and regression weights. The results of the inner model are shown in Table 1 and address H1 to H7. The AVA for the endogenous variables was .174 , and the $\mathrm{R}^{2}$ 's for attitude, believability and intention were greater than the recommended level of .10 by Falk and Miller (1992).

Table 1 Partial Least Squares Results for H1 to H7

\begin{tabular}{lllll}
\hline Predicted variables & Predictor variables & Hyp & Path & $\begin{array}{l}\text { Critical } \\
\text { ratio }\end{array}$ \\
\hline Attitude to Issue & Involvement & H1 & $.39^{*}$ & 6.99 \\
& Believability & H5 & $.21^{*}$ & 3.92 \\
\hline Attention to ads & Involvement & H2 & .015 & 0.23 \\
& Believability of ads & H3 & $.13^{*}$ & 2.40 \\
\hline Believability & Involvement & H4 & $.34^{*}$ & 6.50 \\
\hline Intention to Comply & Attitude to Issue & H6 & $.56^{*}$ & 11.6 \\
\hline AVA & .17 & & & \\
\hline
\end{tabular}

* Significant

The regression weights were moderate to high as shown in Figure 1. A reasonable criterion for evaluating the significance of the individual paths is the absolute value of the product of the path coefficient and the appropriate correlation coefficient. Because paths are estimates of the standardized regression weights, this produces an index of the variance in an endogenous variable explained by that particular path, and $1.5 \%(.015)$ of the variance is recommended as the cut-off point. Variance due to the path were above the recommended level (except for involvement-attention to ads). In Table 1, all the paths exceed this criterion, and the bootstrap critical ratios are of the appropriate size (greater than $1.96, \mathrm{p}<.05$ for two-tailed test or $\mathrm{p}<$ 1.645 for one-tailed test, that is all t-values were all significant and the regression weights were acceptable. 


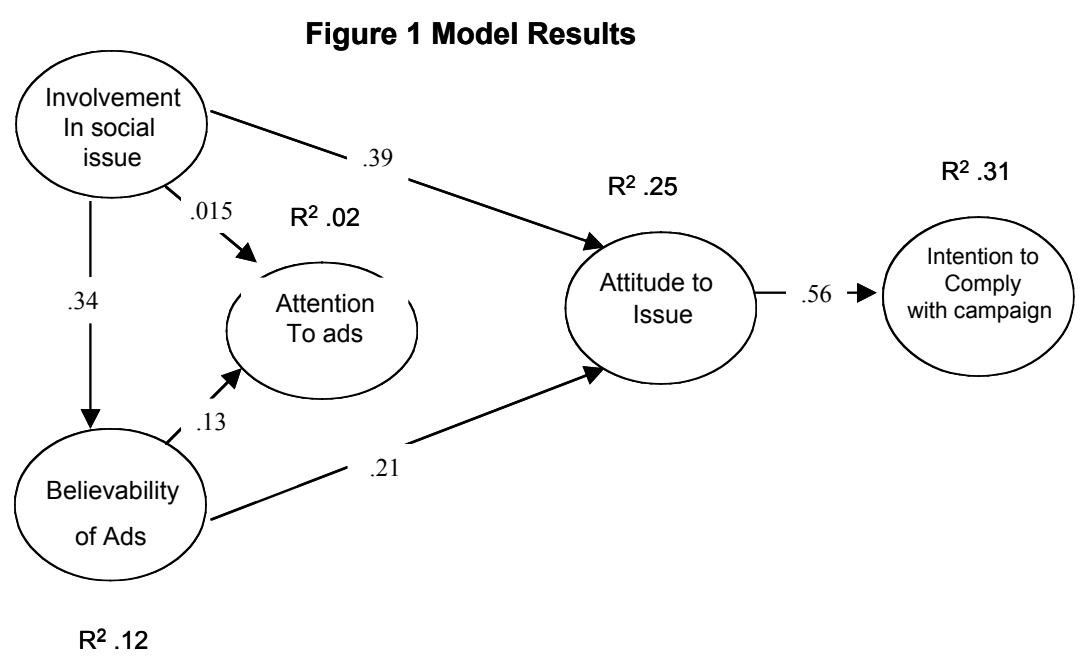

Discussion

The results of the study indicate social issue involvement influences attitude towards the issue, suggesting that once an individual is involved in an issue, they form stronger, more positive attitudes towards that issue. In addition, social issue involvement determines the degree to which an individual believes the message or theme of the advertisement, framed by the social marketing campaign. Thus, the more involved one is in the social issue, the more one would tend to believe the message in the social advertisement. The believability of social advertisements was also found to be significant because of its positive effect on attention paid to ads and attitude towards the issue. Hence, an ad that is seen to be believable in its portrayal of the consequences of an aberrant social behaviour (e.g. "Every cigarette is doing you damage') should result in more attention paid to the message and a more positive attitude towards the social issue. Further, it would seem that social marketers should consider ad believability when designing effective social advertisements, because as indicated by the results, ad believability influences attention and attitude, and attitude has an effect on intention to comply. This suggests that ad believability may be an important component in an individual's intention to comply with a social marketing campaign - and eventual behavioural outcomes. Thus, the aim of an anti-smoking ad should be to increase a smoker's belief that 'every cigarette is doing you damage'. Such belief should result in the formation of a more positive attitude towards the anti-smoking issue, which (hopefully) should translate into a greater intention to stop smoking.

Given that social marketers are using advertising to discourage social issue related behaviours such as smoking or drinking to excess, it would seem the effectiveness of the ads may be determined to some extent, by such factors as the degree to which individuals believe the theme or message of the ad. In particular, these results highlight some of the difficulties faced by social marketers, because if the ad is only believable to those involved in the positive behaviour, what purpose does social advertising serve in the decision process of stopping aberrant social behaviours? This appears to be the crux of the argument, particularly so in the context of the significant growth in use and money being spent on social advertising.

\section{Limitations \& Future Research}

Limitations of the study were the social issues selected as the products associated with these issues (i.e. tobacco and alcohol) are seen to be addictive. While accepting this limitation, the 
social advertisements used as stimuli did not allude to the addictive aspect of products, rather, the focus of the message was on consequences. Other limitations of the study were the type of respondents, the choice of constructs and the method of survey administration. However, given that social marketers utilise social advertising, further research on ad believability and attention paid to the ad in relation to social advertising and intention to comply with social marketing campaigns could provide a greater understanding of their influence on those individuals who practise aberrant social behaviours. This could be done through examining the believability of differing appeals and corresponding involvement, attention and attitudes across different issues.

\section{References}

Ajzen, I 1985, 'From intention to actions: a theory of planned behaviour," in Action Control: From Cognition to Behaviour, eds J Kuhl, \& J Beckman, Springer-Verlag, New York, pp. 11-39.

Andreasen, A 1995, Marketing social change, Jossey-Bass, San Francisco.

Andrews, J C, Netemeyer RG \& Durvasula, S 1990, 'Believability and attitudes toward alcohol

warning label information: the role of persuasive communications theory', Journal of Public Policy \& Marketing, vol.9, pp. 1-15.

Andrews, JC, Netemeyer RG \& Durvasula, S 1991, 'Effects of consumption frequency on believability and attitudes towards alcohol warning labels', Journal of Consumer Affairs, vol. 25, no. 2, pp. 323-338.

Beltramini, RF 1982, 'Advertising perceived believability scale', Proceedings of the Southwestern Marketing Association, eds DR Corrigan, FB Kraft, \& RH Ross, Southwestern Marketing Association, Wichita State University, Wichita, pp. 1-3.

Beltramini, RF 1988, 'Perceived believability of warning label information presented in cigarette advertising', Journal of Advertising, vol.17, no. 1, pp. 26-32.

Burton, S \& Lichtenstein, DR 1988, 'The effect of ad claims and ad context on attitude toward

the advertisement', Journal of Advertising, vol.17, no. 1, pp. 3-11.

Buchholz, LM \& Smith, RE 1991, 'The role of consumer involvement in determining cognitive

response to broadcast advertising', Journal of Advertising, vol. 20, no.1, pp. 4-17.

Carroll, T 1996, A Submission to the National Drug Strategy Evaluation, 1996, The role of social

marketing campaigns within Australia's National Drug Strategy, Research and Marketing Group, Commonwealth Department of Health and Family Services, Canberra.

Falk, RF \& Miller, NB 1992, A primer for soft modelling, University of Akron Press, Akron, $\mathrm{OH}$.

Fazio, RH, Powell, MC \& Williams, CJ 1989, 'The role of attitude accessibility in the attitude-

to-behaviour process', Journal of Consumer Research, vol. 16, December, pp. 280288.

Fishbein, M \& Ajzen, I 1975, Belief, attitude, intention, and behaviour: an introduction to theory

and research, Addison-Wesley, Reading, MA. 
Fornell, C \& Cha, J 1994, 'Partial Least Squares' in Advanced Methods of Marketing Research,

ed. RP Bagozzi, Basil Blackwell Ltd., Oxford.

Fornell, C \& Larcker, DF 1981, 'Evaluating structural equation models with unobservable variables and measurement error', Journal of Marketing Research, vol. 18, pp. 39-50.

Gaski, JF \& Nevin, J 1985, 'The differential effects of exercised and unexercised power sources

in a marketing channel', Journal of Marketing Research, vol. 22, May, pp. 130-142.

Gill, JD, Grossbart, S \& Laczniak, RN 1988, 'Influence of involvement, commitment and familiarity on brand beliefs and attitudes of viewers exposed to alternative ad claim strategies', Journal of Advertising, vol. 17, no. 1, pp. 33-43.

Gotlieb, JB \& Sarel, D 1991, 'Comparative advertising effectiveness: the role of involvement and

source credibility', Journal of Advertising, vol. 20, no. 1, pp. 38-45.

Greenwald, AG \& Leavitt, C 1984, 'Audience involvement in advertising: four levels', Journal

of Consumer Research, vol. 11, June, pp. 581-592.

Hair, J, Anderson, R, Tatham, R \& Black, W 1998, Multivariate Data Analysis, 5edn, Prentice-

Hall International, Inc.

Hajjat, M 2003, 'Effect of cause-related marketing on attitudes and purchase intentions: the moderating role of cause involvement and donation size', Journal of Nonprofit \& Public Sector Marketing, vol. 11, no. 1, pp. 93-110.

Higgins, K, Cooper-Stanbury, M \& Williams, P 2000, Statistics on drug use in Australia 1998 ,

AIHW cat.no. PHE16. Canberra: AIHW (Drug Statistics Series).

Kokkinaki, F \& Lunt, P 1999, 'The effect of advertising message involvement on brand access-

Ibility', Journal of Economic Psychology, vol. 20, pp. 41-51.

Kotler, P \& Andreasen, AR 1996, Strategic Marketing for NonProfit Organisations, $5^{\text {th }}$ edn, Prentice Hall Inc, New Jersey.

Laczniak, RN, Muehling, DD \& Grossbart, S 1989, 'Manipulating message involvement in advertising research', Journal of Advertising, vol. 18, no. 2, pp. 28-38.

Laczniak, RN \& Muehling, DD 1993, 'Toward a better understanding of the role of advertising

message involvement in ad processing', Psychology and Marketing, vol.10, July/August, pp. 301-319.

Lee, H, Herr, PM, Kardes, FR \& Kim, C 1999, 'Motivated search: effects of choice accountability, issue involvement, and prior knowledge on information acquisition and use', Journal of Business Research, vol. 45, no. 1, pp. 75-88.

Mano, H 1997, 'Affect and persuasion: the influence of pleasantness and arousal on attitude formation and message elaboration', Psychology \& Marketing, vol. 14, no. 4, pp. 315335.

Mittal, B 1990, 'The relative roles of brand beliefs and attitude toward the ad as mediators of 219. brand attitude: a second look', Journal of Marketing Research, vol. 27, May, pp. 209-

Neece, WT \& Caprella,analwsils d996,the ' indepetredient influen' across

involvement environments: when attitude toward the ad predicts purchase intentions', Journal of Promotion Management, vol. 4, no. 1, pp. 89-109. 
O'Cass, A 2000, 'An assessment of consumers product, purchase decision, advertising and consumption involvement in fashion clothing', Journal of Economic Psychology, vol. 21, pp. 545-576.

O'Cass, A 2001, 'Consumer self-monitoring, materialism and involvement in fashion clothing', Australasian Marketing Journal, vol. 9, no. 1, pp. 46-60.

O'Cass, A 2002, 'Political advertising believability and information source value during elections', Journal of Advertising, vol. 31, no. 1, pp. 63-74.

Pechmann, C, \& Reibling, ET 2000, 'Planning an effective anti-smoking mass media campaign targeting adolescents', Journal of Public Health Management and Practice, vol. 6, no. 3, pp. 80-94.

Peracchio, LA \& Luna, D 1998, 'The development of an advertising campaign to discourage smoking initiation among children and youth', Journal of Advertising, vol. 27, no. 3, pp. 49-56.

Petty, RE \& Cacioppo, JT 1979, 'Issue involvement can increase or decrease persuasion by enhancing message-relevant cognitive responses', Journal of Personality and Social Psychology, vol. 37, pp. 1915-1926.

Petty, RE, Unnava, RH \& Strathman, AJ 1991, 'Theories of attitude change' in Handbook of consumer behaviour, eds T S Robertson \& HH Kassarjian, Prentice Hall, Englewood Cliffs, NJ.

Sheppard, BH, Hartwick, J \& Warshaw, PR 1988, 'The theory of reasoned action: a metaanalysis of past research with recommendations for modifications and future research', Journal of Consumer Research, vol. 15, December, pp. 325-343.

Snyder, M \& Kendzierski, D 1982, 'Acting on one's attitudes: procedures for linking attitude and

behaviour', Journal of Experimental Social Psychology, vol. 18, pp. 165-183.

Wolburg, JM 2001, "The "risky business" of binge drinking among college students: using risk

models for psas and anti-drinking campaigns', Journal of Advertising, vol. 30, no. 4, pp. 23-39.

Zaichkowsky, JL 1985, 'Measuring the involvement construct', Journal of Consumer Research,

Vol. 12, December, pp. 341-352. 